\title{
Pohjoinen ulottuvuus eurooppalaisen yhteistyön työkaluna
}

Pohjoinen ulottuvuus on Suomen vuonna 1997 tekemä EU-poliittinen aloite, joka pyrkii edistämään tasavertaista kumppanuutta unionin, Venäjän, Norjan ja Islannin välillä. Aloitteen taustalla ovat Suomen kansainväliset ja EU-poliittiset intressit, mutta samalla se on heijastanut EU:n ulkopoliittisen toimijuuden muutosta. Artikkeli tarkastelee Pohjoisesta ulottuvuudesta vuodesta 1997 käytyä keskustelua historiantutkimuksen näkökulmasta diskurssihistoriallista lähestymistapaa hyödyntäen. Suomen ulkopoliittisten toimijoiden puheet, virkamiesten, poliitikkojen ja alue- ja paikallistason toimijoiden haastattelut, Pohjoisesta ulottuvuudesta eduskunnassa käyty keskustelu sekä eräät aiheeseen liittyvät poliittiset asiakirjat osoittavat, kuinka eurooppalaisen naapuruuspolitiikan ja EU-Venäjä-suhteiden kehitys on vaikuttanut Pohjoisen ulottuvuuden politiikan tavoitteisiin ja sisältöihin sen eri vaiheissa ja kuinka Suomi on pyrkinyt luovimaan EU-solidaarisuuden ja erityisen Venäjäsuhteensa asettamien vaatimusten välillä. Pohjoinen ulottuvuus on muuttunut 1990-Iuvun lopulta Suomen johtavasta EU-poliittisesta pohjoisen Euroopan alueellistamiseen tähtäävästä visiosta epäpoliittiseksi ja käytännönläheiseksi kumppanuustyöksi, jota suomalaiset markkinoivat Euroopan unionille toimivana Venäjä-yhteistyön työkaluna.

\section{Alina Kuusisto}

Vuonna 1995 toteutuneen EU-jäsenyyden myötä Suomesta ryhdyttiin rakentamaan aktiivista toimijaa pohjoisen Euroopan alueelle ja erityisesti suhteessa Venäjään. Pääministeri Paavo Lipposen vuonna 1997 julkisuuteen tuoma ja vuonna 1999 EU-politiikaksi virallistettu Pohjoisen ulottuvuuden aloite korosti ennen kaikkea EU:n ulkosuhteita ja sen kansainväli- 
sen toimijuuden vahvistamista. Lipposen mukaan tavoite ei ollut vain Suomen ja pohjoisen profiilin nostaminen ja etujen ajaminen, vaan rauhan ja vakauden edistäminen koko unionissa ja sen lähialueilla. (Lipponen 1997, 29-35; Lipponen 1998, 125-132; Heikkilä 2006, 16.) Pohjoinen ulottuvuus tarjoaa näkökulman eurooppalaisen yhteistyön rakentumiseen kylmän sodan jälkeisellä aikakaudella. Se antaa mahdollisuuden tarkastella EU:n toimijuutta kaksisuuntaisena prosessina, jossa unioni vaikuttaa kansalliseen poliittiseen puheeseen ja toimintaan ja jossa kansalliset näkökulmat ja intressit muokkaavat EU-politiikkaa (Jokela 2011, 24-26; Miller 2012, 38).

Aiemmassa tutkimuksessa on painotettu Suomen ulkopolitiikan nopeaa eurooppalaistumista EU-jäsenyyden myötä, sekä maan hakeutumista eurooppalaisten valtioiden ydinryhmään. (Esim. Jokela 2011, 47-75; Rytövuori-Apunen 2007, 18, 31-32). Kuten Ojanen ja Raunio $(2018$, 43-51) toteavat, Suomi on aktiivisesti pyrkinyt vaikuttamaan unionin Venäjänpolitiikkaan ja tuonut omia intressejään EU:n areenalle. Samalla se on painottanut unionin yhtenäisyyttä sekä monenkeskiseen yhteistyöhön perustuvaa linjaa. Pohjoinen ulottuvuus kuvastaa myös Euroopan unionin tavoitetta vahvistaa ulko- ja naapuruuspoliittista agendaansa. Unioni on pyrkinyt edistämään reuna-alueille sijoittuvaa monenvälistä yhteistyötä, jota Pohjoisen ulottuvuuden ohella edustavat esimerkiksi Välimeren kumppanuus, Mustanmeren yhteistyö ja Itämeren strategia. EU:n rooli eri alueellisissa ulottuvuuksissa ja niihin kytkeytyvissä politiikoissa ja ohjelmissa vaihtelee, mutta yhteistä sille on paitsi pyrkimys alueellisen yhteistyön vahvistamiseen ulottuvuuksien sisällä, myös päätavoite vakauden, demokratian, rauhan ja vaurauden edistämisestä koko maanosassa (Cottey 2012, 375-383).

Unionin ulottuvuuksiin perustuva politiikka kytkeytyi EU:n itälaajenemiseen ja sen tueksi muotoiltuun naapuruuspolitiikkaan (ENP), jonka lähtökohdat ja tavoitteet kirjattiin Euroopan komission vuonna 2003 julkaisemassa kommunikeassa Wider Europe - Neighbourhood, A New Framefork for Relations with our Eastern and Southern Neighbours. EU:n pyrkimyksenä oli luoda ystävällisten, vauraiden ja vakaiden ystävien rinki EU:n ympärille ja ehkäistä uusien jakolinjojen syntyä. Unionin asiakirjoissa painotettiin, että ENP tarjoaisi "kaiken, paitsi instituution". (Esim. Smith 2005; Kelley 2006.) Eurooppalaisen naapuruuspolitiikan kehittämisellä ja kuihtumisella on selvä yhteys Pohjoisen ulottuvuuden aseman muutokseen - usko Pohjoisen ulottuvuuden tulevaisuuteen oli vahvimmillaan 1990- ja 2000-luvun vaihteessa, mutta viime vuosina se on lähes kadonnut julkisesta ja poliittisesta keskustelusta.

EU:n ulkosuhteiden tutkimuksen perusoletuksia on ollut, että Euroopan unionin ulottuvuuksiin ja alueellistamiseen perustuva ulkopolitiikka edustaa uudenlaista kansainvälistä toimijuutta, joka eroaa perinteisestä kansalliseen suvereniteettiin nojaavasta valtiojärjestelmästä sekä tavoitteiltaan että toimintamalleiltaan. Kontrastia Venäjään on pidetty tässä suhteessa merkittävänä. Venäjä on nähty toimijana, joka suojelee vaikutusvaltaansa ja rajojaan perinteisin taloudellisin ja sotilaallisin keinoin. Euroopan unionia pidetään tästä näkökulmasta houkuttelevana yhteiskuntamallina, joka pehmeän vallankäytön keinoin pyrkii siirtämään normejaan, arvojaan ja käytäntöjään naapurimaihin. (Averre 2010, 1690-1692; Averre 2011, 6.) Vaikka artikkelin kontekstina on oletus unionin postsuvereenista tai postmodernista luonteesta, on syytä muistaa, että unionin olemuksessa ja tavoitteissa on nähty valtiomaisuutta ja että etenkin sen turvallisuuspolitiikassa on interventionismiin ja vaikutusalueajatteluun viittaavia piirteitä. EU:n on katsottu haastavan valtioiden perinteistä suvereniteettia ja rajoittavan erilaisin instrumentein ja mekanismein näiden kansallista toimivaltaa. (Averre 2010; Johansson-Nogués 2009, 28-31.) 
Tutkimuksessa Pohjoisen ulottuvuuden ja unionin postmodernin luonteen välille vedetään usein yhtäläisyysmerkki (esim. Haukkala 2010, 154; Forsberg \& Haukkala 2016, 211; Sicard Filteborg et al. 2002, 397-402; Catellani 2003, 41; Haglund 2005, 88, 99; Cebesi 2012, 566-569). Käytännössä Pohjoisesta ulottuvuudesta on kuitenkin Suomessa keskusteltu varsin erillään eurooppalaisesta naapuruuspolitiikasta. Suomi tuki avoimesti ENP:n tavoitteita unionin muilla reuna-alueilla, mutta suhteissa Venäjään linjaus oli toinen. Pohjoisen ulottuvuuden voikin ajatella kehittyneen suomalaiseksi versioksi eurooppalaisesta naapuruuspolitiikasta, jossa korostuvat monenkeskisen alueellisen yhteistyön tasa-arvoinen ja kaikkia osapuolia hyödyttävä luonne. Toisin kuin ENP:ssa Pohjoiseen ulottuvuuteen on liitetty pyrkimys aidon kumppanuuden luomiseen, jossa unioni sallii ulkopuolisen toimijan vaikuttaa omaan sisäiseen päätöksentekoonsa (Haukkala 2010, 154-155). Alusta alkaen Venäjällä oli ainakin teoreettinen mahdollisuus vaikuttaa yhteistyön sisältöön ja EU:n sisäisiin poliittisiin prosesseihin, mikä oli oman toimijuutensa vahvistamiseen pyrkivän unionin kohdalla uutta ja poikkesi sen aikaisemmista naapuruusaloitteista.

Tutkimuksissa on toisaalta kritisoitu Pohjoisen ulottuvuuden EU-keskeisyyttä saman tapaisilla argumenteilla kuin ENP:tä (kritiikistä esim. Horký-Hlucháň \& Kratochvil 2014, 252-270; Zaiotti 2007, 143-162; Smith 2005, 757-773). Browningin (2005, 94-95) mukaan Pohjoinen ulottuvuus on osa prosessia, jossa Euroopan unioni pyrkii ulottamaan vaikutusvaltaansa rajojensa ulkopuolelle ja samalla ylläpitämään jakoa meihin ja muihin. Haukkala $(2010,154)$ puolestaan luettelee Pohjoisen ulottuvuuden tunnusmerkkeinä yksipuolisen pyrkimyksen siirtää eurooppalaisia arvoja unionin ulkopuolelle sekä oletuksen, että kaikki kumppanimaat ja etenkin Venäjä hyväksyvät tämän tavoitteen. Vastauksena Venäjän kritiikkiin ja politiikan hitaaseen edistymiseen Suomen ulkoministeriö päätti uudistaa Pohjoisen ulottuvuuden Suomen toisen EU-puheenjohtajuuskauden (vuonna 2006) alla. Suomi markkinoi aktiivisesti kumppanuuden uutta mallia, jonka toivottiin ratkaisevan ENP:n toteutuksessa ilmenneitä ongelmia. Uudistettu Pohjoinen ulottuvuus korosti kumppanuuden ideaa vanhaa vahvemmin. Se käsitteellistyi yhteiseksi politiikaksi, jossa lopullinen päämäärä oli yhteinen omistajuus ja Venäjän tasaveroinen toimijuus. Vähemmän EU-keskeisenä ja ehdollistavana sekä käytännöllisyyttä painottavana sen on nähty edustavan vaihtoehtoista EU:n ulkopolitiikkaa (Haglund-Morrissey 2008, 203-217; Aalto et al. 2008, 9-12).

\section{Artikkelin tavoite ja aineiston analyysi}

Tarkastelen tässä artikkelissa Pohjoisesta ulottuvuudesta käytyjä keskusteluja diskurssin käsitteen kautta. Diskursseja voi luonnehtia kielenkäytössä tuotetuiksi, tietyllä tapaa rajautuviksi puhetavoiksi, jotka sekä hahmottavat erilaisia tulkintoja ja representaatioita sosiaalisesta todellisuudesta että samalla synnyttävät sosiaalista todellisuutta (Jorgensen \& Phillips 2002, 8-13). Näin ymmärrettynä diskurssien merkitys ei jää vain kielen tasolle, vaan ne ovat olennainen osa reaalimaailman todellisuutta. Sovellan tarkastelussa väljästi diskurssihistoriallista lähestymistapaa, jossa tutkimuksen kohdetta arvioidaan historiallisena, yhteiskunnallisena ja kielellisenä ilmiönä (Reisigl \& Wodak 2009, 87-89). Pohdin, miten Pohjoista ulottuvuutta on hyödynnetty suomalaisessa keskustelussa diskursiivisena resurssina ja miten kansallinen ja EU-lähtöinen lähestymistapa näkyvät ja vuorottelevat keskustelun eri vaiheissa. Artikkelin lopuksi tuon yhteen olennaiset keskustelussa esiin nousseet Suomen ulko- ja EU-poliittiseen toimijuuteen liittyvät diskurssit ja pohdin niiden sisältöä suhteessa Pohjoisen ulottuvuuden historiallisiin vaiheisiin sekä EU:n naapuruuspolitiikan ja EU-Venäjä-suhteen kehitykseen. 
Tarkastelussa on nimenomaan Pohjoisesta ulottuvuudesta vuodesta 1997 lähtien käyty suomalainen keskustelu, jota avataan ulkopoliittisten toimijoiden puheiden, eduskuntakeskusteluiden ja hallituksen aineistojen sekä virkamiesten, poliitikkojen ja aluetoimijoiden haastatteluiden kautta. Euroopan parlamentin tai muiden jäsenvaltioiden tulkinnat Pohjoisesta ulottuvuudesta jäävät siis vähemmälle huomiolle.

Monipuolinen lähdeaineisto tukee aihetta eri suunnista lähestyvää tarkastelutapaa. Lähdeaineistona on hyödynnetty Ulkopoliittisen instituutin ylläpitämää kaikille avointa verkkoarkistoa, joka sisältää suomalaisten ulkopoliittisten toimijoiden, kuten presidenttien, ministereiden ja valtiosihteereiden puheita vuosilta 1973-2019. Artikkelin puheita sisältävä aineisto koostuu noin 190 suomenkielisestä ja englanninkielisestä vuosina 1997-2017 pidetystä puheesta, jotka ovat löytyneet verkkoarkistosta hakusanalla "Pohjoinen ulottuvuus". Lisäksi analyysissa on hyödynnetty 20 muualta internetistä löytynyttä Pohjoista ulottuvuutta käsittelevää puhetta. Toisen aineistokokonaisuuden muodostavat Suomen eduskunnan valtiopäiväasiakirjojen sähköisestä hakupalvelusta hakusanalla "Pohjoinen ulottuvuus" löytyvät asiakirjat. Aineisto koostuu pääasiassa täysistuntojen ja suullisten kyselytuntien pöytäkirjoista, kirjallisista kysymyksistä, eräistä valtiokuntien mietinnöistä ja lausunnoista sekä muista asiakirjoista vuosilta 1997-2017. Kolmantena keskeisenä lähdeaineistona ovat suomalaisten virkamiesten, poliitikkojen ja alue- ja paikallistoimijoiden vuosina 2017-2018 toteutetut Pohjoista ulottuvuutta käsittelevät teemahaastattelut, joiden lukumäärä on 23. Haastateltavat esiintyvät artikkelissa nimettöminä, ja haastatteluihin on viitattu haastattelupäivästä, haastateltavan sukupuolesta ja haastattelun järjestysnumerosta koostuvalla koodilla.

Puheita ja valtiopäiväasiakirjoja on analysoitu tarkastelemalla vuosikohtaisesti seuraavia seikkoja: 1) Pohjoisen ulottuvuuden käsitteen eri määrittelyjä, merkityksiä, vaihtoehtoisia käsitteitä ja konteksteja, 2) intressejä eli sitä, kenen politiikaksi Pohjoinen ulottuvuus tekstissä määritellään ja ketä sen katsotaan hyödyttävän, 3) Venäjän roolia, 4) Euroopan unionin roolia sekä 5) näiden toimijoiden välisiä valtasuhteita. Näin tulkitsemalla ja useiden lukukertojen myötä teksteistä alkoi vähitellen hahmottua erilaisia diskursseja sekä käsitys siitä, kuinka Pohjoista ulottuvuutta hyödynnettiin eri vaiheissa diskursiivisena resurssina Suomen EU- ja ulkopolitiikkaa määriteltäessä. Haastattelujen analyysi sen sijaan eteni etsimällä haastattelujen litteraatioista niin sanottuja avaintapahtumia tai tiheitä kohtia (Koski 2011, 136) eli tutkimuskysymysten kannalta relevantteja kuvauksia ja tulkintoja. Näin alkoi muodostua kategorioita, joiden alle kertyi otteita haastatteluista. Toistuvien lukukertojen myötä kategoriat alkoivat yhdistyä yläkategorioiksi ja vähitellen laajemmiksi diskursseiksi. Artikkeli rakentuu löyhälle kronologialle, jonka sisällä keskeiset diskurssit eli kansallisen katseen diskurssi, vahvan unionin diskurssi ja Suomi sillanrakentajana -diskurssi esiintyvät osin vuorotellen, osin päällekkäisinä. Diskurssijärjestys, jonka kautta voidaan hahmottaa erilaisia hallitsevia ja taka-alalla olevia puhetapoja ei näin ollen ole yksiselitteinen tai selväpiirteinen. Pelkistetysti voi kuitenkin todeta, että vahvan unionin diskurssi hallitsi Pohjoinen ulottuvuus -keskustelun alkuvuosina etenkin ulkopoliittisen eliitin puheenparressa, mutta Suomi sillanrakentajana -diskurssi alkoi vahvistua 2000-luvun alussa. Eduskuntakeskustelussa avoin kansallisen katseen diskurssi kulkee kuitenkin punaisena lankana koko käsitellyn ajanjakson.

\section{Tavoitteena Venäjän integrointi Eurooppaan}

Vuosituhannen vaihde oli unionille voimakasta toimivallan kasvun aikaa, jolloin EU-jäsenmaiden yhteistyö syveni niin talouden, ulkopolitiikan, siirtolaispolitiikan kuin sosiaalipoli- 
tiikan alueilla. Samalla EU vahvisti ulkopoliittista rooliaan, mitä osoitti sen aktivoituminen pohjoisessa rajojensa ulkopuolelle ulottuvissa kysymyksissä. (Kaelble 2009, 195-196; Raunio \& Saari 2017, 12.) Unionin laajenemisen ja vahvistumisen ansiosta usko Pohjoisen ulottuvuuden mahdollisuuksiin oli korkealla etenkin Suomessa. Pohjoinen ulottuvuus oli ennen kaikkea Suomen EU-poliittinen strategia, mutta EU-Venäjä-suhteiden näkökulmasta sillä oli kantoa myös unionissa. Idealle vanhoja kategorioita rikkovasta valtioiden rajat ylittävästä yhteistyöstä ja alueenrakennuksesta antoi tilaa Venäjän Eurooppa-myönteinen ilmapiiri ja EU:n ja Venäjän suotuisasti kehittyvä suhde.

Suomen ulkopoliittinen johto esitti Pohjoisen ulottuvuuden 2000-luvun alkuvuosille asti EU:n politiikkana, jonka edistämisessä Suomella oli aktiivinen rooli. Se painotti EU:n vetovastuuta ja koko unionin alueelle ulottuvia hyötyjä, mikä osoitti maan ulko- ja turvallisuuspoliittisen diskurssin eurooppalaistumista. Ensimmäisinä jäsenyysvuosinaan Suomi pyrki pääministeri Paavo Lipposen johdolla aktiivisesti EU:n ytimeen ja osoittamaan, kuinka Suomen ja EU:n edut olivat yhteiset. Suomi ilmaisi varauksetonta tukeaan integraatiokehitykselle ja pyrki olemaan aloitteentekijä ulko- ja turvallisuuspoliittisissa kysymyksissä ja erityisesti unionin yhteisen Venäjän politiikan rakentamisessa. (Jokela 2011, 62-63; Ojanen \& Raik 2017, 170-172; Raunio \& Saari 2017, 17-19.) Kuten Suomen hallituksen turvallisuus- ja puolustuspoliittinen selonteko vuodelta 2001 osoittaa, Suomen poliittinen johto näki Pohjoisen ulottuvuuden EU:n Venäjän politiikan ja sitä kautta lähialueiden turvallisuuden ylläpitämisen keskeisenä strategiana:

Suomi osallistuu aktiivisesti EU:n pohjoisen ulottuvuuden toimintaohjelman toteuttamiseen, joka tarjoaa pitkän tähtäyksen toimintamallin kestävän turvallisuuden vahvistamiseen Suomen lähialueella. Venäjän EU-politiikan kehittyminen luo mahdollisuuksia yhteistyöhankkeille, jotka edistävä myös turvallisuushaasteiden ratkaisemista. (VNS 2/2001 vp, s. 35.)

Poliittisen eliitin puhetavassa vahvan unionin diskurssi oli siis vuosituhannen vaihteessa hallitseva. Siinä painotetaan EU:n tai yhteisen eurooppalaisen toimijuuden lujittamista ja pyritään välttämään kansallisten lähtökohtien korostamista ja pohjoinen-etelä -vastakkainasettelua. Koko unionin hyötyä ja jaettuja intressejä painottamalla haluttiin vahvistaa Pohjoisen ulottuvuuden uskottavuutta muualla unionissa. Esimerkiksi presidentti Martti Ahtisaaren vuosien 1997-1999 Pohjoiseen ulottuvuuteen kytkeytyneitä puheita luonnehtii EU:n etujen ja toimijuuden korostuminen sekä suhde Venäjään: unionista haluttiin tehdä tehokkaampi globaali toimija. Puheissa korostuvat markkinatalous, kaupan esteiden poistaminen ja EU:n mahdollisuudet hyödyntää pohjoisen (Venäjän) luonnonkaasu- ja raakaöljyesiintymiä sekä unionin kilpailukyvyn parantaminen. Ahtisaari sitoutui puheissaan EU:n pyrkimyksiin integroida Venäjä lähemmin läntiseen Eurooppaan, jolloin Venäjä näyttäytyy politiikan kohteena ja yhtä aikaa sekä haasteiden että mahdollisuuksien alueena.

Kuten Suomen hallituksen aloitteesta syntyvä EU:n Pohjoinen ulottuvuus on muille EU-kumppaneillemme osoittanut, tällä ilmansuunnalla on mittaamattomia resursseja. On kaikkien EU-maiden etujen mukaista, että niitä hyödynnetään. (Ahtisaari 1999.)

Haluan kuitenkin lyhyesti mainita Pohjoista ulottuvuutta koskevan aloitteemme, jonka olemme esittäneet EU:ssa. Tämän aloitteen tavoitteena on luoda EU:lle johdonmukainen 
Euroopan pohjoisten alueiden politiikka. Tällä politiikalla pyrittäisiin tukemaan Venäjän kytkemistä maailmantalouteen. Tavoite on viimeaikaisten tapahtumien vuoksi käynyt entistäkin tärkeämmäksi. Pohjoisen ulottuvuuden politiikka tähtää EU:n itälaajentumisen edistämiseen sekä EU:n strategisten energiapoliittisten tavoitteiden varmistamiseen. (Ahtisaari 1998.)

Ahtisaaren puheet ilmensivät EU:n tavoitteita edistää monenkeskisen yhteistyön mallia sekä postsuvereenia agendaa suhteessa Venäjään. Vaikka Venäjän tarjoamaa taloudellista hyötyä korostettiin puheissa vuoden 1998 jälkeen vähemmän, oli niiden huomio edelleen Venäjän sitouttamisessa ja Eurooppaan suuntautuvan integraation edistämisessä. Ahtisaaren puheet ja Pohjoisen ulottuvuuden julkilausutut tavoitteet onkin asetettava 1990-luvun lopun Euroopan geopoliittiseen kontekstiin. Venäjän länsimaistumista pidettiin Suomessa yhteisenä tavoitteena ja katsottiin, että Pohjoinen ulottuvuus heijasti myös Venäjän politiikkaa:

\footnotetext{
Tämähän oli sitä aikakautta, kun uskottiin siihen, että olisi edellytyksiä edetä EU:n ja Venäjän välisessä yhteistyössä integraation suuntaan. Ja sitä kautta ikään kuin oletettiin, että Venäjä oli matkalla oikeusvaltion ja normaalin demokratian suuntaan. Tämä oli tämmöinen optimistinen, positiivinen agenda, että askel askeleelta EU ja Venäjä integroituu yhä enemmän ja tämän positiivisen integraation, keskinäisriippuvuuden, myötä sitten konfliktiriskit vähenevät. (071217M1.)
}

EU ja Venäjä allekirjoittivat vuonna 1994 kunnianhimoisen Kumppanuus- ja yhteistyösopimuksen (PCA). Sopimuksen päämääränä oli edistää paitsi talouselämää myös poliittista keskustelua, sosiaalipolitiikkaa, kulttuuria, koulutusta ja tutkimusta. Se perustui oletukseen, että Venäjä oli ottamassa askeleita kohti markkinataloutta sekä demokratian ja ihmisoikeuksien syvempää kunnioittamista. Vaikka EU:n ja Venäjän lämmenneet suhteet kokivat kolauksen Venäjän 1998 alkaneen talouskriisin sekä Tšetšenian ja Kosovon konfliktien seurauksena, olivat Neuvostoliiton hajoamisen jälkeiset vuodet 1990-luvun lopun Venäjällä länsiorientoitunutta vaihetta, jolloin EU-yhteistyö ja jopa unionin jäsenyys nähtiin houkuttelevina mahdollisuuksina. (Forsberg \& Haukkala 2016, 18-22; Haukkala 2015, 26-30.) EU:n Venäjä-tavoitteet näyttivät Suomen kannalta relevanteilta ja niiden uskottiin edistävän Venäjän integroitumista eurooppalaiseen yhteisöön.

Vaikka Venäjä koki tulleensa petetyksi EU:n arvostellessa Venäjän toimintaa Tšetšenian ja Kosovon sodissa (Prozorov 2006, 26), oli ilmassa edelleen yhteistyön myönteisen kehittymisen merkkejä. Venäjän presidentiksi vuonna 1999 valitun Vladimir Putinin ensimmäisen kauden alku merkitsi EU:n ja Venäjän uudelleen viritellyn suojasään aikaa Tšetšenian kriisin jäädessä vähitellen taka-alalle. Putin suhtautui myönteisesti Venäjän eurooppalaistumiseen etenkin taloudellisessa mielessä ja totesi puheessaan Saksan vierailulla syyskuussa 2001: "Mitä tulee Euroopan yhdistymiseen, me emme vain tue tällaisia prosesseja, vaan näemme niissä myös toivoa" (Forsberg \& Haukkala 2016, 24; Haukkala 2015, 30.) Kuten Pohjoisen ulottuvuuden syntyvaiheessa 1990-luvun puolivälin jälkeen, EU:n ja Venäjän yhteistyön myönteiseen kehitykseen suhtauduttiin 2000-luvun alun Suomessa optimistisesti.

Suomalainen keskustelu Pohjoisesta ulottuvuudesta oli diskursiivisesti kaksitasoista. Suomen ulkopoliittinen eliitti julisti 1990-luvulla vahvan unionin diskurssin mukaisesti pyrkivänsä EU:n ytimeen ja asettavansa unionin toimijuuden vahvistamisen yksittäisen jäsenmaan etujen edelle. Samalla kotimaan eduskuntakeskusteluissa kansallisen katseen 
diskurssi oli vahva ja Suomen intressejä ajettiin peittelemättä. Kansallisen katseen diskurssiin liittyy Suomen aluepoliittisten intressien korostaminen ja kilpailu EU:n resursseista. Vuonna 1997 Pohjoinen ulottuvuus tuli esiin unionin maatalouspolitiikan Agenda 2000 -asiakirjan käsittelyssä, jossa huomio kiinnitettiin Suomen maatalouden tuotanto-olojen vaikeuksiin ja erityispiirteisiin (PTK 163/1997). Tässä keskustelussa EU ja muut jäsenmaat näyttäytyivät ennemmin haastajina kuin liittolaisina. Alueellisista ja maakunnallisista lähtökohdista asiaa tarkastelleita kansanedustajia EU:n ulkopoliittisen toimijuuden korostaminen turhautti. Pohjoisen ulottuvuuden politiikkaa pidettiin epäkonkreettisena ja Suomen kannalta epäonnistuneena ja huomio haluttiin suunnata esimerkiksi tietoliikenne- ja liikenneverkkojen kehittämiseen Suomesta Venäjälle tai Barentsin alueen kaasu- ja muiden luonnonvarojen hyödyntämiseen (PTK 92/1999, ss. 3092-3093'; PI 11/1999, s. 1129²).

Ministerit ja jotkin kansanedustajat suitsivat näitä kannanottoja ja tähdensivät Pohjoisen ulottuvuuden hyötyä koko Euroopalle. Silloinen valtionvarainministeri, sittemmin tasavallan presidentti Sauli Niinistö, painotti EU:n ja Venäjän keskinäisiä suhteita: "Suomen pohjoiset alueet ovat hivenen eri kysymys kuin Pohjoinen ulottuvuus, jolla luodaan siis poliittista ulottuvuutta unionin ulkopuolellekin, joka sitten avaa erilaisia yhteistyömahdollisuuksia" (PTK 92/1999, s. 3093). Unionin naapuruuspolitiikan, "ystävien ringin", rakentaminen tuli esiin myös turvallisuutta tähdentäneissä kannanotoissa. Sosiaalidemokraattien kansanedustaja Antero Kekkosen mielestä Pohjoinen ulottuvuus oli tehokas pitkän tähtäimen instrumentti EU:n ja Venäjän välillä, sillä olennaista oli Venäjän sitominen kestävään turvallisuuskumppanuuteen (PTK 87/2001, s. 6). Outi Ojala näki Pohjoisen ulottuvuuden myös vaihtoehtoisena turvallisuusratkaisuna Naton sijaan. Tällöin Suomen intresseissä oli luoda yhteistyön verkosto EU-maiden ja Naton välille (PTK 87/2001).

\section{Pohjoisen ulottuvuuden uudistaminen}

Pohjoisen ulottuvuuden yhdeksi vaikeudeksi osoittautui EU:n Venäjä-suhteen ikuisuusongelma, eli kykenemättömyys luoda johdonmukaista ja yhtenäistä Venäjä-politiikkaa. Ongelma korostui entisestään unionin ja Naton itälaajenemisen myötä, sillä entisen Neuvostoliiton maiden asenteet Venäjää kohtaan olivat kielteisiä (Nitoiu 2014, 239-241). Kylmän sodan jälkeen EU:sta ja Natosta oli tullut Euroopan keskeisiä turvallisuustoimijoita, jotka pyrkivät vahvistaman asemaansa idässä ja edistämään sitä kautta Euroopan vakautta ja turvallisuutta. Euroopan turvallisuuskysymyksiin keskittyneessä akateemisessa tutkimuksessa tämän on tulkittu lisänneen Venäjän epäluuloa EU:n ja Naton motiiveja kohtaan. On nähty, että Venäjä koki tulleensa syrjäytetyksi ja että sen intressejä ja integraatiopyrkimyksiä entisen Neuvostoliiton alueella haastettiin. Unionin naapuruuspoliittisen diskurssin rinnalla EU:ssa onkin nähty sellaisen vallankäytön piirteitä, joka asettaa etusijalle strategiset ja taloudelliset intressit sekä pyrkimyksen ratkaista naapurialueidensa aseellisia konflikteja (Averre 2010; Averre 2016).

On arvioitu, että Venäjä-elementin hyödyntäminen Pohjoisen ulottuvuuden markkinoinnissa koitui lopulta Pohjoisen ulottuvuuden tappioksi ja miinoitti aloitteen alkuperäisen monenkeskisen ja hajautetun luonteen Venäjä-suhteen geopoliittisilla ongelmilla (Gebhard 2013, 379-381). Venäjä-elementti toistui ja vahvistui ulkopoliittisissa puheissa 2000-luvun alussa, selvästi ennen politiikan virallista uudistamista, ja ohitti pian EU-lähtöisen puhetavan ja vahvaa unionia korostaneen diskurssin. Venäjän erityisasemaa ja Suomen Venäjäasiantuntemusta ja välittäjän roolia alleviivannut Suomi sillanrakentajana -diskurssi alkoi vahvistua. Johtavat ulkopoliittiset toimijat alleviivasivat, kuinka venäläisten tavoitteet ja 
tarpeet oli otettava huomioon. Heidän mukaansa Suomella oli Venäjään liittyvää erityistietämystä ja siten kompetenssia toimia ikään kuin neuvonantajana EU:1le. Pohjoinen ulottuvuus oli muutettava "aidoksi jaetuksi politiikaksi", eikä asetelma voinut olla se, että "EU kertoo Venäjälle mitä se aikoo tämän politiikan alalla tehdä”.

Tulemme pohjoisesta ja tarjoamme yhteiseen käyttöön osaamisemme myös lähiympäristöstämme. Tavoitteemme on uudistaa Pohjoinen ulottuvuus aidosti EU:n, Venäjän, Norjan ja Islannin yhteiseksi politiikaksi. (Halonen 2006.)

Pidän tärkeänä, että Pohjoisen ulottuvuuden politiikkaa yhä kehitetään. Sen työstämisessä on tärkeää pitää mielessä se, että tulevia ohjelmia kehitetään tiiviissä kumppanuudessa Venäjän kanssa. Kysymyksessä ei voi olla se, että EU kertoo Venäjälle mitä se aikoo tämän politiikan alalla tehdä, vaan toiminnan pitää perustua hyvälle yhteisymmärrykselle ja yhteisille intresseille. (Vanhanen 2004.)

Yllä lainatuissa Tarja Halosen ja Matti Vanhasen puheissa viitataan Venäjän haluttomuuteen sitoutua alkuperäiseen, EU-keskeisenä pitämäänsä Pohjoisen ulottuvuuden politiikkaan. Voi myös pohtia, heijastavatko Halosen ja Vanhasen näkemykset kritiikkiä eurooppalaista naapuruuspolitiikkaa kohtaan laajemmin. Kuitenkin myös Suomessa oli 1990-luvun lopulla etenkin aluetasolla ja elinkeinoelämän keskuudessa lähdetty rohkeasti markkinoimaan Pohjoista ulottuvuutta ja kohdeltu Venäjää ennen kaikkea potentiaalisena raaka-aineresurssina. Siirtymä vahvan unionin diskurssista sillanrakentajadiskurssiin näyttäytyy siten melko selkeänä. Kuvaavia ovat haastateltavien esimerkit siitä, kuinka 2000-luvun taitteessa eri puolilla Suomea järjestetyissä Pohjoisen ulottuvuuden foorumeissa suomalaisten yritysten edustajat esittelivät kartoissaan naapurimaan luonnonvaroja venäläisedustajien seuratessa esitystä eturivistä (170118N1; 130618M2). Vaikka Venäjän omissakin intresseissä oli yhteisen eurooppalaisen energia-alueen luominen, koettiin peittelemätön kiinnostus maan energiavaroja kohtaan maan johdossa lähinnä kolonialistisena. Lisäksi Pohjoisen ulottuvuuden ensimmäistä toimintasuunnitelmaa pidettiin Venäjällä epäkonkreettisena ja kapea-alaisena. Toistuvaa kritiikkiä sai myös erillisen budjettilinjan tai rahaston puuttuminen, eli tavoite rahoittaa Pohjoisen ulottuvuuden alaisia projekteja jo olemassa olevien rahoitusohjelmien puitteissa. (110618M3; Shlyamin 2004, 68, 110-111.)

Vuosista 2003-2004 eteenpäin ulkoministeriön puheissa ryhdytään unionin intressien sijaan painottamaan Pohjoisen ulottuvuuden hyötyä koko Euroopalle ja usein suoraan Venäjälle. Ulkoministeri Erkki Tuomioja totesi lokakuussa 2005 ympäristökumppanuudesta puhuessaan, kuinka "[n]ämä projektit ovat tasapuolisesti ja elinvoimaisesti tärkeitä sekä unionille että Venäjälle. Välittömiä hyötyjiä ovat kaikki asukkaat ei vain tässä osassa Eurooppaa vaan koko Euroopassa" (Tuomioja 20053). Suomen toisen puheenjohtajuuskauden alla ja aikana vuosina 2005-2006 sekä eduskuntakeskusteluissa että ulkopoliittisten vaikuttajien puheissa korostettiin, kuinka Pohjoisen ulottuvuuden politiikasta haluttiin rakentaa EU- ja Venäjäyhteistyön väline. Unionin ja Venäjän strategisten suhteiden kehittäminen ja uudistaminen esitettiin Suomen puheenjohtajuuskauden keskeiseksi teemaksi, minkä voi nähdä kritiikkinä aiemmalle EU:n Venäjä-politiikalle. "EU:n ja Venäjän suhteiden perustaa tulee uudistaa", totesi pääministeri Matti Vanhanen eduskunnassa 21.6.2006 (PTK 76/2006, s. 11).

Uudistusvaiheessa Pohjoinen ulottuvuus sidottiin kiinteästi EU:n ja Venäjän neljän yhteisen tilan (The Four Common Spaces) luomiseen, josta oli sovittu osapuolten yhteisessä huippu- 
kokouksessa Pietarissa vuonna 2003. Yhteiset tilat koskivat taloutta ja ympäristöä; vapautta, turvallisuutta ja oikeutta; ulkoista turvallisuutta; sekä tutkimusta ja koulutusta. Toisin kuin unionin aiemmat Venäjä-strategiat tai ENP, neljän yhteisen tilan politiikka pyrki painottamaan Venäjän erityistä asemaa ja ottamaan sen mukaan politiikan suunnittelun prosesseihin. Myös retorisesti se edusti uudenlaista EU-Venäjä -yhteistyön diskurssia, jossa tavoitteena ei ollut yksipuolisesti muuttaa Venäjää kohti unionin määrittelemiä standardeja. (Van Elsuwege 2008.) Suomalainen Pohjoinen ulottuvuus -keskustelu oli varsin tulevaisuussuuntautunutta ja siinä viitattiin harvoin vanhan Pohjoisen ulottuvuuden heikkouksiin tai siihen, mitä unionin Venäjä-politiikassa oli muutettava. Pääministeri Matti Vanhanen kuitenkin kiinnitti Pohjoisen ulottuvuuden rahoitusta käsittelevässä puheenvuorossaan kesällä 2005 huomiota unionin naapuruuspolitiikan ongelmiin ja linjasi näin Pohjoisen ulottuvuuden pesäeroa ENP:hen:

\begin{abstract}
Komissio esitti naapuruussuhdeinstrumenttia erääksi rahoitusvälineeksi, ulkosuhderahoitusvälineeksi, ja kun Venäjä ei toden totta pidä itseään naapuruuspolitiikan kohteena, mitä se ei ole, muun muassa Suomen tavoitteiden mukaisesti tämä on nyt muutettu rahoituskehitysneuvotteluissa naapuruus- ja kumppanuusinstrumentiksi, ja se kumppanuus-sana tarkoittaa Venäjää. (PTK 69/2005, s. 45.)
\end{abstract}

Merkillepantavaa on Pohjoisen ulottuvuuden uudistamisen jälkeinen retoriikan muutos suomalaisessa aineistossa. Politiikan hyötyjïä ei enää eritelty yhtä konkreettisesti kuin aikaisemmin, ja toimijoina esiintyivät EU:n ja kumppanimaiden sijaan pääasiassa Pohjoinen ulottuvuus ja sen kumppanuudet, alueelliset neuvostot sekä muut pohjoisen alueellisen yhteistyön toimijat ja ohjelmat. Retoriikan muutos epäpolitisoi Pohjoista ulottuvuutta ja osoittaa, kuinka vahvan unionin diskurssi heikkeni siitä, mitä se 1990-luvulla oli ollut. Pohjoisen ulottuvuuden sanansaattaja Paavo Lipponen oli joutunut väistymään pääministerin paikalta vuoden 2003 eduskuntavaalien seurauksena, eikä Suomi esittänyt enää yhtä aktiivisesti pyrkivänsä unionin ytimeen. Toisaalta EU oli entistä hajanaisempi Irak-kysymyksen ja itälaajenemisen vuoksi. Kuten Hanna Ojanen ja Kristi Raik $(2017,180)$ toteavat, ”EU [ei] enää näyttänyt ratkaisevan tärkeältä”.

Suomen julkilausuttuna pyrkimyksenä oli tehdä Pohjoisesta ulottuvuudesta unionin laajasti tunnustama ja siihen resursseja käyttävä yhteistyöinstituutio, jolloin se EU-jäsenmaana saattoi hyötyä unionin vahvistuvasta asemasta pohjoisessa. On esitetty, että nojautumalla voimakkaasti unioniin Suomi olisi hukannut idänpoliittisen suuntansa ja puhdistanut Venäjäsuhteistaan kaiken erityisyyden (Rytövuori-Apunen 2007, 18, 32, 69). Kansallinen Pohjoinen ulottuvuus -keskustelu kuitenkin osoittaa, että Suomi pyrki jo 2000-luvun alussa, vuosia ennen PU:n virallista uudistamista, haastamaan EU-lähtöisen puhetavan ja rakentamaan Pohjoisesta ulottuvuudesta uudenlaista monenkeskistä yhteistyömuotoa, jossa Venäjällä oli tasaveroinen paikka EU:n rinnalla. Pohjoisen ulottuvuuden uudistamisen vuonna 2006 voi tästä näkökulmasta tulkita toistaiseksi viimeiseksi yritykseksi kehittää EU-Venäjä-suhteita ja ENP:tä monenkeskisen tasa-arvoisen yhteistyön suuntaan.

\title{
Kilpailu pohjoisen käsitteellistämisestä
}

Parlamentaarinen Pohjoiseen ulottuvuuteen liittyvä keskustelu oli aktiivisimmillaan Suomen ensimmäisen EU-puheenjohtajuuskauden yhteydessä vuonna 1999, jolloin tietoisuutta politiikan tavoitteista ja sisällöstä pyrittiin laajentamaan ja selventämään. Toinen aktiivinen 
keskusteluvaihe ajoittui Suomen toisen puheenjohtajuuskauden ympärille vuosille 2004-2007. Tällöin esillä oli paitsi politiikan uudistaminen EU-Venäjä -suhteen ja naapuruuspolitiikan kontekstissa myös ja ennen kaikkea Pohjoisen ulottuvuuden suhde muihin pohjoisen Euroopan yhteistyömuotoihin. Keskustelua sävytti 2000-luvun alussa voimakas kritiikki aloitteen vähäistä konkretiaa ja muualla Euroopassa saavuttamaa heikkoa uskottavuutta kohtaan sekä pettymys Venäjän sitoutumattomuuteen. Yhdessä unionin käsillä olleen itälaajenemisen kanssa nämä sysäsivät pohtimaan Suomen roolia Euroopan pohjoisessa politiikassa. Eduskunnassa kysymystä nosti esiin etenkin Vihreän Liiton kansanedustaja, Kööpenhaminan rauhantutkimuslaitoksen johtajana, aluetutkijana ja Pohjois-Karjalan maakuntajohtajana tunnetuksi tullut Tarja Cronberg, joka vaati Pohjois-Euroopan yhteistyön uudelleenarviointia ja päällekkäisyyksien karsimista:

Suomen tulisikin määritellä uudelleen tavoitteensa pohjoisen Euroopan yhteistyössä, sen puitteet ja painopistealueet, sekä järjestää tarvittavat voimavarat. Eduskunnan tulee olla tässä suhteessa aloitteellinen ja pyrkiä muodostamaan tarvittava kokonaiskuva. (KA 13/2004.)

Cronbergin missiona oli muodostaa pohjoiseen Eurooppaan uusi ja vahvempi instituutio, erityinen parlamentaarinen elin, jossa olisivat mukana Euroopan unioni, Pohjoismaat, kaikki Itämeren maat sekä Venäjä. Kyse olisi ollut institutionaalisen elimen luomisesta Pohjoisen ulottuvuuden politiikalle ja sen rahoituksen vakiinnuttamisesta. Laaja pohjoiseurooppalainen yhteistyökuvio olisi vahvistanut Pohjoisen ulottuvuuden painoarvoa ja kytkenyt PohjoisEuroopan pohjoiset alueet ja Itämeren alueen saman katto-organisaation alle. Uusi elin olisi koonnut yhteen alueen eri neuvostot eli Pohjoismaiden neuvoston, Itämeren alueen neuvoston, Arktisen neuvoston, Barentsin euroarktisen neuvoston sekä Pohjoisen ulottuvuuden. Keskeinen rooli olisi etenkin tehottomuudestaan kritiikkiä saaneella Pohjoismaiden neuvostolla, jonka varat toimisivat uuden instituution pohjavaroina. (KA 13/2004.)

Ehdotus yhteisestä pohjoiseurooppalaisesta instituutiosta ei edennyt eduskuntakeskusteluja pidemmälle. Sen sijaan huomio siirtyi Pohjoisen ulottuvuuden ja kehitteillä olleen EU:n Itämeri-strategian keskinäiseen suhteeseen. Aktiivisimpia suomalaisia Itämeri-poliitikkoja oli europarlamenttiedustaja, sittemmin pääministeriksi edennyt Alexander Stubb (Euroopan kansanpuolue), joka kuului vuonna 2005 perustettuun Baltic Europe Intergroup -ryhmään yhdessä kuuden muun mepin kanssa. Ryhmä hahmotteli ensimmäisen luonnoksen Euroopan unionin kokonaisvaltaiseksi Itämeri-strategiaksi, jota Ruotsi ryhtyi ajamaan omalla puheenjohtajakaudellaan ja joka lopulta vuonna 2009 hyväksyttiin Euroopan neuvostossa unionin ensimmäisenä yhteisenä suuraluestrategiana. Stubbin ja muiden europarlamentaarikkojen esityksessä korostettiin Itämeren strategian ja Pohjoisen ulottuvuuden yhteyttä ja painotettiin Itämeren roolia Pohjoisen ulottuvuuden keskeisimpänä alueena (Kosov \& Gribanova 2016). Aleksander Stubbin ja muiden Itämeri-asioita esillä pitäneiden poliitikkojen mielestä Itämeren alueen painoarvon kasvattaminen Pohjoisen ulottuvuuden sisällä lisäisi samalla pohjoisuuden painoarvoa unionissa. Baltic Europe Intergroupin tavoitteena ei ollut luoda Pohjoisen ulottuvuuden tilalle uutta alueellista käsitettä, vaan siirtää sen painopistettä kohti Itämerta ja nostaa samalla Itämeren alueen profiilia. Tämän Alexander Stubb totesi Euroopan parlamentin Itämeri-keskustelussa marraskuussa 2006: 
Raportilla on kolme tavoitetta. Yksi: tukea Pohjoista ulottuvuutta. Kaksi: tehdä Itämerestä Pohjoisen ulottuvuuden painopistealue - uskomme vakaasti, että sen pitäisi olla Pohjoisen ulottuvuuden avainalue. Kolme: haluamme kasvattaa tietoisuutta Itämerestä brändinä, käsitteenä. ${ }^{4}$ (Stubb 2006.)

Ulkoasiainvaliokunnan mietinnön "Itämeri ja Pohjoinen ulottuvuus" (UaVM 7/2007 vp) julkaiseminen 2007 synnytti Suomen eduskunnassa vilkkaan keskustelun paitsi siitä, miten Itämeren tilan ja yhteistyön eteen tuli toimia myös siitä, mikä oli Itämeren strategian ja Pohjoisen ulottuvuuden politiikan suhde. Itämeri-strategia ja Pohjoinen ulottuvuus olivat valiokunnan näkemyksen mukaan omia erillisiä politiikkojaan, jotka kuitenkin tukivat vahvasti toisiaan. Mietinnössä linjattiin, kuinka Pohjoinen ulottuvuus oli Suomen näkökulmasta EU:n ja Venäjän välisen yhteistyön toimeenpanoa Luoteis-Venäjällä ja sen toimintakenttä oli Itämeren aluetta laajempi. Itämeri-strategia taas oli pääasiassa EU:n sisäistä politiikkaa, toisin kuin Pohjoinen ulottuvuus, jossa korostettiin politiikan yhteistä omistajuutta unionin ja kumppanimaiden välillä. Valiokunnan näkemys oli, että Itämeren painoarvoa tuli nostaa sekä unionin että Suomen politiikassa, mihin hyvän mahdollisuuden antaisi vuonna 2009 edessä häämöttänyt Ruotsin EU-puheenjohtajuuskausi. (UaVM 7/2007 vp.)

Osassa kansanedustajia ulkoasiainvaliokunnan linjaukset herättivät huolestumista Pohjoisen ulottuvuuden politiikan jäämisestä Itämeri-strategian varjoon. Laajemmin kysymys oli pohjoisimpien alueiden asemasta eurooppalaisessa politiikassa. Oululainen keskustapuolueen kansanedustaja, sittemmin europarlamentaarikkona toiminut Mirja Vehkaperä totesi seuraavaa:

Pohjoisessa Suomessa tämä Pohjoinen ulottuvuus nähdään Pohjoismaiden ja Venäjän pohjoisten alueiden politiikkana. Meille asia kiteytyy Barentsin alueen toiminnaksi. [---] Vaikka pohjoisen ulottuvuuden yksi tärkein prioriteetti on juuri Itämeri, ei minusta pohjoista aluetta saa unohtaa. (PTK 70/2007 vp, s. 37.)

Keskustelussa myös muistutettiin, että Pohjoinen ulottuvuus oli syntynyt Itämerta laajempana käsitteenä ja sellaisena se tuli myös säilyttää. Vaikka ulkoasiainvaliokunnan mietinnössä Pohjoista ulottuvuutta ei täysin sivuutettu, oli muutos selvä verrattuna 1990-luvun keskusteluihin, joissa Barentsin aluetta pidettiin Pohjoisen ulottuvuuden keskeisenä toimintakenttänä.

Pohjoisen ulottuvuuden uudistaminen vuonna 2006, sen painottuminen yhä enemmän EU:n ja Venäjän välisiin suhteisiin sekä viime kädessä politiikan painoarvon väheneminen EU:n ja Venäjän suhteen kriisiytymisen myötä lievensivät vähitellen näkökulmien välistä vastakkainasettelua. Syntyi jonkinlainen yhteisymmärrys siitä, että Itämeren strategia EU:n sisäisenä ja Pohjoinen ulottuvuus ulkopoliittisena työvälineenä täydensivät toisiaan ja antoivat molemmat Suomelle kanavan edistää omia tavoitteitaan EU:ssa. Itämeren strategian eteneminen Euroopan neuvoston ja komission käsittelyssä täsmensi sen suhdetta Pohjoiseen ulottuvuuteen ja siirsi painotusta aloitteen sisäpoliittiseen luonteeseen. Toisin kuin Euro-Baltic Intergroupin alkuperäisessä esityksessä Euroopan neuvosto ja komissio tekivät selvän eron Itämeri-strategian ja unionin ulkoisen yhteistyön välillä ja totesivat, että suhteet kolmansiin maihin tuli hoitaa nimenomaan Pohjoisen ulottuvuuden kautta. (Kosov \& Gribanova 2016.)

Itämeren ohella toinen Pohjoiselle ulottuvuudelle kilpailevaksi katsottava pohjoista alueellisuutta rakentanut käsite on ollut arktisuus, joka on viime vuosikymmeninä lyönyt itsensä voimakkaasti läpi EU:ssa. Vähemmälle huomiolle on kuitenkin jäänyt se, että myös 
Pohjoiselle ulottuvuudelle pyrittiin rakentamaan omaa arktista ikkunaa. Aloitteentekijänä tässä toimi Tanska ja sen Pohjois-Atlantin ja Jäämeren välissä sijaitseva itsehallintoalue Grönlanti. Grönlannin hallituksen vuonna 1999 tekemän Arktinen ikkuna -esityksen tavoitteena oli rakentaa siltoja arktisten ja ei-arktisten maiden välille ja kiinnittää huomiota etenkin alkuperäiskansojen asemaan. (Tomala 2017; Loukacheva 2007.) Kun arktiset alueet 2000-luvun edetessä laajemmin kiinnittivät EU:n huomion, myös Suomi ryhtyi painottamaan Pohjoisen ulottuvuuden merkitystä unionin arktisen politiikan toteuttamisen välineenä. Arktinen nousi näkyväksi geopoliittiseksi kysymykseksi vuonna 2007, jolloin ilmastonmuutos ja merijään sulaminen sekä kilpailu alueen luonnonvarojen hyödyntämisestä ilmaantuivat otsikoihin. Euroopan unioni tiivisti arktista politiikkaansa vuodesta 2008 lähtien. Vuosina 2008, 2012 ja 2016 julkaistut kolme arktista tiedonantoa raamittivat unionin arktista politiikkaa, jonka on katsottu perustuneen olemassa oleviin sopimuksiin ja monenkeskisiin yhteistyömekanismeihin sekä kunnioittavan arktisten valtioiden keskeistä roolia arktisina toimijoina. (Raspotnik 2018; Numminen 2011; Østhagen 2013; Conde Pérez \& Yaneva 2016.)

Pohjoisesta ulottuvuudesta ei tullut EU:n arktisen politiikan menestystarinaa, vaikka Tukholmassa vuonna 2009 järjestetyssä Pohjoisen ulottuvuuden virkamiestapaamisessa ja Oslossa vuonna 2010 pidetyssä ministeritapaamisessa kiinnitettiinkin huomiota Arktisen ikkunan potentiaaliin. Erityisen tärkeänä pidettiin alkuperäiskansojen edustajien kutsumista mukaan Pohjoisen ulottuvuuden prosesseihin. (Chairman's conclusion 2009; Joint statement 2010.) Pohjoisen ulottuvuuden arktinen ikkuna jäi tuntemattomaksi kansallisessa poliittisessa keskustelussa, ja myös EU-tasolla sen voi laskea yhdeksi monista hiipuneista alueellisista aloitteista. Andreas Raspotnikin (2018, 70-90) mukaan Pohjoista ulottuvuutta ja sen arktista ikkunaa olisi pitänyt käyttää tehokkaammin arktisen tietoisuuden lisäämiseksi unionissa. Toisaalta EU:n arktista politiikkaa on kritisoitu liiallisesta keskittymisestä ulkopoliittiseen ulottuvuuteen sen sijaan, että se olisi kiinnittänyt huomiota oman sisäisen arktisen politiikkansa (Pohjois-Ruotsi ja Pohjois-Suomi) kehittämiseen (Østhagen 2013, 85-86). Suomessa Pohjoiselle ulottuvuudelle on kuitenkin viime vuosina pyritty hakemaan uutta nostetta arktista tematiikkaa hyödyntämällä. Mustan hiilen odotetaan olevan Pohjoisen ulottuvuuden ja varsinkin sen ympäristökumppanuuden seuraava käytännön kohdealue (170118N2; 090218M4; 170118N4; 170118N5).

\section{Poliittinen käsite epäpolitisoituu}

Uudistamisensa jälkeen Pohjoinen ulottuvuus on tarkoittanut pitkälti käytännön hankkeiden ja asiantuntijoiden yhteistyön parissa operoivien kumppanuusohjelmien toimintaa. Kumppanuusohjelmista ensimmäinen, ympäristökumppanuus, perustettiin jo vuonna 2001 ja se osoittautui kumppanuuksista menestyksekkäimmäksi etenkin merkittävien Venäjällä toteutettujen vedenpuhdistamohankkeiden ansiosta. Nykyisin kumppanuuksia on kaikkiaan neljä, joista sosiaali-ja terveyskumppanuus perustettiin vuonna 2003, liikenne- ja logistiikkakumppanuus vuonna 2009 ja kulttuurikumppanuus vuonna 2010. On arvioitu, että keskittyminen kumppanuuksien puitteissa yhteistyöteemoihin, jotka korostetusti ovat kaikkien osapuolten yhteisesti hyväksymiä ja joiden rahoittamiseen kaikki kumppaniosapuolet osallistuvat, on kapeuttanut aloitteen toiminta-aluetta ja häivyttänyt sen alkuperäistä arvopohjaisuutta. Samalla se on kuitenkin lisännyt mahdollisuuksia toiminnan jatkamiseen tilanteessa, jossa EU:n ja Venäjän välit ovat jatkuvasti kiristyneet (Busygina \& Filippov 2008, 205-211). Suomalaisten virkamiesten haastatteluissa todetaan, että ulko- ja turvallisuuspolitiikka on tietoisesti pidetty 
ulkona Pohjoisen ulottuvuuden agendalta:

$[\mathrm{P}]$ oliittisen tason keskustelut, nehän on pidetty pois tuolta PU-agendalta. Siellä ei ole puhuttu turvallisuuspolitiikasta tai mistään tämmösestä. Ja se on ollu sillon se onnistumisen avain, että ne on pidetty sieltä pois, aivan samalla tavalla kun Arktisessa neuvostossa tai Itämeren maiden neuvostossa, tai tällä tavalla. Ne on tarkoituksella rajattu sieltä veks, että sitten voidaan käydä sitä aitoa dialogia. (090218M5)

Me ei edistetä oikeusjärjestelmäreformia eikä kansalaisyhteiskuntaa tai ihmisoikeuksia, niinku nyt tällä hetkelläkin ja kautta vuosien, niin ympäristö on sellainen yleisesti hyväksytty helppo yhteistyöaihe. (170118N4)

[J]os ajatellaan kulttuurikumppanuutta, niin kyllä se loppuun lopuks on ollut tosi vähäistä se vaikutus. Et me ollaan kuitenkin pystytty toteuttamaan näitä meijän töitä ja se kulttuuri on sitten vaikeimpina hetkinä ehkä nähty semmosena kanavana, joka on auki ja sitä voidaan hyödyntää ja kaikki jotenkin myöskin haluaa sen tehdä. (080218N6)

Putinin jälkeen vuonna 2008 presidentiksi valitun ja Venäjän modernisaatiota ajaneen Dmitri Medvedevin kaudella Venäjä oli lähentynyt unionia (Forsberg \& Haukkala 2016, 31-32; Moshes 2012, 17, 21). Yhteistyö ei kuitenkaan konkretisoitunut käytännössä, sillä varsin pian EU alkoi muuttua Venäjän silmissä strategisesta liittolaisesta kilpailijaksi. Venäjä jätettiin pois vuonna 2009 vahvistetusta Itäisestä kumppanuudesta (Eastern Partnership), jonka avulla EU tiivisti yhteistyötään Armenian, Azerbaidzhanin, Valko-Venäjän, Georgian, Moldovan ja Ukrainan kanssa. Lisäksi Georgian ja Syyrian sodat vahvistivat entisestään EU:n kriittisyyttä Venäjän ulkopolitiikkaa ja ihmisoikeustilannetta kohtaan. Kun Ukrainan kriisi puhkesi vuonna 2014, olivat EU:n ja Venäjän välit olleet jo pitkään jännittyneet ja ongelmalliset (Pop 2016, 53-56). Samana vuonna voimaan astuneet EU:n Venäjälle asettamat talouspakotteet alkoivat rajoittaa kansainvälisten rahoituslaitosten investointeja Venäjälle, mikä käytännössä pysäytti ympäristökumppanuuden alaisen hanketoiminnan. Muuttuneessa tilanteessa Venäjä alkoi suomalaisten virkamiesten mukaan suhtautua Pohjoiseen ulottuvuuteen entistä myönteisemmässä valossa. "[M]utta tää on ihan silmiin pistävää tällä hetkellä nyt näissä kansainvälisissä kokouksissa, että Venäjä haluaa PU:ta" (170118N2). Etenkin ulkoministeriössä uskotaan Pohjoisen ulottuvuuden toimivan Venäjälle väylänä jatkaa sitä hyödyttävää alueellista yhteistyötä, jota myös arvostetaan sen tasavertaisuuden vuoksi.

Pohjoinen ulottuvuus on osoittanut arvopohjaisen ja monenkeskisen politiikan yhdistämisen ongelmallisuuden. Ongelma ei kuitenkaan ole enää Venäjän kriittisyys, vaan ulkoministeriön näkökulmasta suurin haaste on jo pitkää ollut saada EU vakuuttuneeksi Pohjoisen ulottuvuuden tarpeellisuudesta. Ulkoministeriössä nähdään, että ainoa väylä varmistaa politiikan jatkuvuus on saada EU uskomaan sen olevan hyödyllinen työkalu EU:lle tämän Venäjä-suhteiden ja etenkin Arktisen politiikan kehittämisessä. Hankalaksi Suomen kampanjoinnin on kuitenkin tehnyt pelko Venäjän mahdollisista Pohjoisen ulottuvuuden yhteistyöhön liittyvistä ei-toivotuista tarkoitusperistä. Huolena on, että Venäjä pyrkii ylläpitämään suhteita EU-maihin kuten ennenkin, edistämään kahdenvälistä kanssakäymistä ja synnyttämään juopaa EU-maiden välille. 
Että kyl hyvin samaa viestiä on tullut myös näinä vaikeimpina viime vuosina Venäjältä, että he eivät ole sitä jättämässä, vaan katsovat, että on hyvä juttu ja jatkakaamme. Sehän palvelee - niinkun mä puhuin siitä, että heillä on pyrkimyksenä näyttää, että ollaan niinku palaamassa nollaolotilaan business as usual ja tämähän palvelee sitä, heidän tarkoitustaan. Sehän on hyvä tiedostaa, että heillä on vähän niinkun taka-ajatuksiakin siinä mielessä. Mut okei, jos on tämmöisiäkin taka-ajatuksia niin se myös hyödyttää meitä, myönteinen suhtautuminen. (170118N1.)

Pohjoisen ulottuvuuden politiikkaa edistäessään Suomi joutuu näin ollen tasapainottelemaan kahden tavoitteen välillä. Toisessa vaakakupissa painavat solidaarisuus ja sitoumukset unionin Venäjän sanktiopolitiikkaa kohtaan ja perinne tukea yhtenäistä ja vahvaa EU:ta, mikä ilmenee vahvan unionin diskurssissa. Kristi Raik $(2015,449)$ painottaa, ettei Suomen sitoutuminen unioniin perustu yksinomaan kansallisiin turvallisuus- ja talousintresseihin, vaan kyse on myös aidosta sosiaalistumisesta yhteisöön ja sen arvoihin. Toisaalta unioniin sitoutuminen on sen kasvavan hajaannuksen vuoksi käynyt vaikeammaksi, mikä näkyy esimerkiksi jäsenmaiden poikkeavissa suhtautumistavoissa EU:n Venäjän sanktiopolitiikkaan. Ulkopoliittisena toimijana Suomi on viime vuosina esiintynyt sekä monenkeskisen yhteistyön ja rauhan edistäjänä että esimerkkinä toimivista kahdenvälisestä Venäjä-suhteesta (Ojanen \& Raik 2017, 188). Tämä on merkinnyt Suomi sillanrakentajana -diskurssin vahvistumista. Pohjoista ulottuvuutta on pyritty tuomaan esiin Venäjä-yhteistyön rakenteena, josta kannattaa pitää kiinni. Ulkoasiainvaliokunta painotti valtioneuvostolle tammikuussa 2019 antamassaan lausunnossa Pohjoisen ulottuvuuden olevan "Suomen ja EU:n etujen mukaista tarjoten konkreettisen ja käytännönläheisen välineen sektoreiden väliselle yhteistyölle, erityisesti ympäristö- ja ilmastoyhteistyölle" (UaVL 14/2018). Myös Suomen kolmannen EU-puheenjohtajakauden ohjelma mainitsee Pohjoisen ulottuvuuden ja korostaa sen asemaa Venäjään liittyvän valikoivan kanssakäymisen välineenä:

Lisäksi on tärkeää, että EU jatkaa johdonmukaista ja yhtenäistä Venäjä-politiikkaa, mukaan lukien pakotteissa. Venäjään liittyen valikoiva kanssakäyminen, ihmisten välisten yhteyksien edistäminen ja alueellinen yhteistyö muun muassa ympäristön suojelemiseksi ovat unionin intresseissä. Pohjoisen ulottuvuuden politiikassa on tähän sopivia välineitä. (Kestävä Eurooppa 2019, 12.)

Pohjoisen ulottuvuuden erityisyys, monenkeskinen tasa-arvoinen yhteistyö, on ollut sille sekä menestystekijä että haitta. Suomessa Pohjoisen ulottuvuuden tasa-arvoisuutta on pidetty piirteenä, joka on tehnyt siitä erityisen. Tasa-arvoisuus on mahdollistanut toimivan ja konkreettisen kumppanuusmallin, jonka avulla on päästy tuloksekkaaseen yhteistyöhön Venäjän kanssa alueilla, joissa se ei ehkä muuten olisi onnistunut, etenkin ympäristökysymyksissä. Samalla alkuperäiset unionin postmoderniin toimijuuteen liittyvät tavoitteet ovat jääneet taka-alalle ja Pohjoista ulottuvuutta on ryhdytty markkinoimaan Suomessa ennen kaikkea tasaveroisena yhteistyövälineenä suhteessa Venäjään.

\section{Pohjoinen ulottuvuus ulkopoliittisena diskurssina}

Suomalaisessa poliittisessa keskustelussa Pohjoinen ulottuvuus on ollut diskursiivinen resurssi, jossa heijastuu ajallinen muutos sekä käsitteen monitasoisuus. Historiallisia kiinnekohtia 
tuovat Suomen asemoituminen idän ja lännen välissä Venäjän naapurina ja integroituminen Euroopan unioniin, EU:n sisäinen kehitys sekä unionin suhde Venäjään. Artikkelissa Pohjoisen ulottuvuuden kansallista keskustelua on tarkasteltu väljästi etenevän kronologisen rakenteen pohjalta. Keskustelu alkaa Pohjoisen ulottuvuuden EU-keskeisyyden korostamisesta, etenee yrityksenä ratkoa Venäjän vahvistuvaan toimijuuteen liittyviä ongelmia ja epäpolitisoitumista ja päättyy siihen, kuinka Pohjoista ulottuvuutta on jälleen lähdetty nostamaan esiin osana Suomen EU- ja Venäjä-politiikkaa. Diskursiivisena resurssina Pohjoinen ulottuvuus -keskustelua ei kuitenkaan voi suoraan asettaa aikajanalle, vaan erilaiset Suomen ulkopoliittista puhetta luonnehtivat kilpailevat diskurssit ovat osin päällekkäisiä ja ajoitukseltaan epäselviä. Keskustelusta on kuitenkin tunnistettavissa kolme toisistaan selkeästi erottuvaa puhetapaa, eli kansallisen katseen diskurssi, vahvan unionin diskurssi ja Suomi sillanrakentajana -diskurssi. Ne ilmentävät Suomen 1990- ja 2000-luvun erilaisia ulkopoliittisia strategioita osana EU:ta ja Venäjän naapurina.

Kansallisen katseen diskurssissa Pohjoinen ulottuvuus esiintyy Suomi-keskeisenä ja suomalaisiin intresseihin perustuvana politiikkana. Euroopan unioni puolestaan näyttäytyy perustaltaan kansallisiin intresseihin nojautuvana toimijana, jossa kansalliset, usein taloudelliset, edut viime kädessä määrittelevät sen politiikan suuntaa ja ohittavat yleiset tavoitteet esimerkiksi yhteisistä eurooppalaisista arvoista tai turvallisuudesta. Pohjoisen ulottuvuuden etenemisen "hintana" on ollut EU-lähtöisen arvopuheen ja intressien jääminen taka-alalle sekä toiminnan suuntaaminen niille alueille, joilla osapuolten on helppo löytää yhteisiä päämääriä.

Pohjoinen ulottuvuus edustaa pyrkimystä edistää tasa-arvoista ja monenkeskistä kansainvälistä yhteistyötä, joka palvelee Suomen ulkopoliittisia tarpeita suhteessa Euroopan unioniin ja Venäjään. Voi ajatella, että Suomen mahdollisuudet määritellä unionin politiikkaa Pohjoisen ulottuvuuden kontekstissa olivat vahvimmillaan politiikan syntyvaiheessa, jolloin unioni Suomen ja Ruotsin jäsenyyden myötä ensi kertaa laajeni Itämeren pohjoispuolelle. Tällöin käytiin aktiivista keskustelua uuden Euroopan pohjoisen käsitteellistämisestä, ja alueen toimijarakenteet olivat vasta muotoutumassa. Pohjoinen ulottuvuus oli vahvasti politisoitunut käsite, jonka avulla haluttiin synnyttää Eurooppaan uusi toiminta-alue, jonka rakentamisessa Suomella olisi aktiivinen ja keskeinen rooli ja jolla olisi merkitystä sekä unionin sisällä että laajemmassa kansainvälisessä kontekstissa. Samalla Suomi pyrki vaikuttamaan unionin Venäjä-politiikkaan ja vahvistamaan sitä, mille antoi pohjan usko EU:n ja Venäjän suhteiden suotuisaan kehitykseen.

Pohjoinen ulottuvuus on käynyt jatkuvaa kilpailua johtavan pohjoisen aluekäsitteen asemasta. Eduskunnassa esitettiin 2000-luvun alusta lähtien voimistuvaa kritiikkiä Pohjoisen ulottuvuuden epäkonkreettisuutta ja hidasta etenemistä kohtaan sekä keskusteltiin siitä, mikä pohjoisen alueellinen yhteistyömuoto olisi nimenomaan Suomen kannalta edullisin. Etenkin kokoomuksen piirissä tavoiteltiin Itämeren profiilin nostamista myös Pohjoisen ulottuvuuden politiikan sisällä, mikä auttamatta korosti aloitteen aluepoliittista luonnetta. Vastakkain olivat Pohjoisen ulottuvuuden pohjoista ja Itämeren aluetta korostaneet painotukset. Yhtä lailla arktisen nousu laaja-alaisena, mutta samalla hyvin konkreettisena käsitteenä on heikentänyt Pohjoista ulottuvuutta. Toisaalta arktisen esiinmarssi on nostattanut toiveita pohjoisen Euroopan kysymysten vahvistumisesta unionin kiinnostuksen kohteina.

Vahvan unionin diskurssissa Pohjoista ulottuvuutta voi tarkastella Euroopan unionin pyrkimyksenä vahvistaa vaikutustaan Euroopan pohjoisilla alueilla ja edistää postsuvereenia toimijuuttaan. Tällöin kyse on nimenomaan EU-lähtöisestä strategiasta vaikuttaa pohjoisten alueiden geopoliittisiin, maidenvälisiin, kulttuurisiin ja lainsäädännöllisiin poliittisiin tiloihin. 
(Delcour 2011; Sicard Filteborg et al. 2002.) Vahvan unionin diskurssi korostaa EU:n vahvaa toimijuutta, johon Suomi diskursiivisesti tukeutui etenkin ensimmäisen EU-puheenjohtajuuskautensa yhteydessä 1990-luvun lopulla. Uutta eurooppalaista EU-identiteettiään rakentava Suomi halusi integroitua unioniin ja edistää sen tiiviyttä ja yhteisiä arvoja. Kyse ei ollut vain unionin välineellisestä hyödyntämisestä, vaan aidosta sosiaalistumisesta eurooppalaisiin ideaaleihin (Raik 2015, 449).

Vahvoista kansallisista lähtökohdista huolimatta Pohjoisen ulottuvuuden politiikkaa on rakennettu niillä reunaehdoilla, joita unionin ylhäältä alas suuntautuva toimijuus asettaa. Pohjoinen ulottuvuus heijastaa Euroopan unionin ulkopoliittisen aseman muutosta sekä sitä, minkälaista monikansallista ja rajat ylittävää yhteistyötä se on milloinkin halunnut suosia. EU:n ja Venäjän välit ovat kiristyneet, unionin jäsenmaiden suhtautuminen Venäjään on eriytynyt ja kansallismielisyys on noussut Euroopassa vieden pelitilaa Pohjoisen ulottuvuuden kaltaiselta monenkeskiseltä poliittiselta käsitteeltä. Pohjoisesta ulottuvuudesta ei myöskään ole ollut "uuden pohjoisuuden" viralliseksi politiikaksi. Tämä johtuu pohjoisen alueen hajanaisuudesta ja kilpailevien alueellisten käsitteiden runsaudesta. Euroopan unionin komissio ja neuvosto halusivat kehittää Pohjoista ulottuvuutta ensisijaisesti unionin Venäjä-työkaluna, mutta sekin tavoite menetti merkitystään unionin ja Venäjän suhteiden vaikeutuessa Suomen toisen puheenjohtajuuskauden jälkeen. Pohjoisen ulottuvuuden jatkon kannalta olennainen kysymys onkin, onko EU tulevaisuudessa valmis edistämään sellaista pohjoisen yhteistyön politiikkamallia, johon Venäjä on halukas lähtemään mukaan.

Suomi on Pohjoisen ulottuvuuden kautta etsinyt tapaa profiloitua EU:ssa ja asemoitua suhteessa kahteen suureen kansainväliseen toimijaan. Suomi sillanrakentajana -diskurssissa nouseekin esiin Suomen historiallinen kokemus välittäjäasemasta idän ja lännen suurvaltojen ja niiden edustamien ideologioiden välissä. Suomi profiloituu diskurssissa aktiivisena kansainvälisenä toimijana, joka kykenee vaikuttamaan sekä EU:n politiikkaan että Venäjän toimintaan. Venäjän tulo EU:n rajanaapuriksi antoi Suomelle kompetenssia muotoilla unionin Venäjää koskevaa ulkopolitiikkaa omista lähtökohdistaan. Suomen mukaan sillä oli Venäjään liittyvää erityistietämystä ja esiintyi ikään kuin neuvonantajana EU:lle. Sillanrakentaja-diskurssia vahvisti ja uudensi 2000-luvun edetessä tulkintaa Pohjoisesta ulottuvuudesta käytännönläheisenä, vakiintuneena ja monenkeskisyyttä edistävänä politiikkana. Pohjoisen ulottuvuuden poikkeuksellisuus EU:n naapuruuspoliittisten ohjelmien joukossa, eli Venäjän tasaveroinen kumppanuus, on tulkittu Suomessa ainoaksi toimivaksi lähtökohdaksi yhteistyössä Venäjän kanssa. Usko Venäjän lähentymiseen kohti Euroopan unionia vaikutti 1990-luvun poliittisessa tilanteessa olleen suomalaisten keskuudessa aitoa, mutta 2010-luvulla alkuperäisen Pohjoisen ulottuvuuden arvopohjaisuus ja integraatiopyrkimykset on nähty toimimattomina. Pohjoisesta ulottuvuudesta käydyssä keskustelussa välittyykin ajatus siitä, ettei Suomi voi nojautua unionin naapuruuspolitiikan perusperiaatteisiin eli toimia normatiivisesti ja toteuttaa arvopohjaista ulkopolitiikkaa suhteessa Venäjään, mutta myös Suomen oma yritys rakentaa tasavertaista kumppanuutta on ajautumassa karille. 


\section{Viitteet}

1 Ks. erityisesti Hannu Ahon ja Paula Lehtomäen puheenvuorot.

2 Ks. erityisesti Esko-Juhani Tennilän puheenvuoro.

3 Kirjoittajan käännös englannista.

4 Kirjoittajan käännös englannista.

\section{Lähteet}

\section{Haastattelut}

170118N1，170118N2, 170118N3，170118N4，170118N5, 080218N6, 071217M1，130618M2, 110618M3, 090218M4, 090218M5 (haastattelijoina Alina Kuusisto ja Joni Virkkunen).

\section{Puheet ja valtiopäiväasiakirjat}

Ahtisaari, Martti (1998), Tasavallan presidentti Martti Ahtisaaren puhe Hampurin senaatin tarjoamalla illallisella 25.9.1998, https://www.eilen.fi/fi/2233/?language=fi (Tarkistettu 25.2.2019).

Ahtisaari, Martti (1999), Tasavallan presidentti Martti Ahtisaaren puhe Espanjan teollisuuden ja työantajain keskusliiton (SEOE) yritysjohtajakokouksessa Madridissa. 3.2.1999, https:/www.eilen. fi/fi/2264/?language=fi (Tarkistettu 25.2.2019).

Chairmans Conclusion (2009), The second senior officials meeting of the renewed Northern Dimension, Stockholm 12.11.2009, http://www.eeas.europa.eu/archives/docs/north_dim/docs/2009_11_north_ dim_summit_conclusions_en.pdf (Tarkistettu 21.2.2019).

Halonen, Tarja (2006), Tasavallan presidentti Tarja Halosen puhe Karlspreis-säätiön seminaarissa Aachenissa 24.5.2006. https://www.eilen.fi/fi/1400/?language=fi (Tarkistettu 25.2.2019).

Joint statement (2010), The second ministerial meeting of the renewed Northern Dimension, Oslo 2.11.2010, http://www.europarl.europa.eu/meetdocs/2009_2014/documents/deea/ dv/0209_0209_06.pdf (Tarkistettu 21.2.2019).

KA 13/2004, Eduskunnan täysistunnon pöytäkirja 30.9.2004, Pohjoisen Euroopan yhteistyön kehittäminen, https://www.eduskunta.fi/FI/Vaski/sivut/trip.aspx?triptype=ValtiopaivaAsiakirjat\&doci $\mathrm{d}=\mathrm{ka}+13 / 2004$ (Tarkistettu 7.8.2019).

Kestävä Eurooppa - kestävä tulevaisuus (2019), Suomen EU-puheenjohtajakauden ohjelma. Euroopan unionin neuvoston puheenjohtajuus 1.7.-31.12.2019. https://eu2019.fi/documents/11707387/14346258/EU2019FI-EU-puheenjohtajakauden-ohjelma.pdf/53e093b3-24b9562f-375a-39cd1 cbe3d31/EU2019FI-EU-puheenjohtajakauden-ohjelma.pdf.pdf (Tarkistettu 7.8.2019).

PI 11/1999, Pääministerin ilmoitus Suomen puheenjohtajuuskauden ohjelmasta 17.6.1999. https:// www.eduskunta.fi/FI/vaski/Poytakirja/Documents/ptk_98+1999.pdf (Tarkistettu 27.9.2019).

PTK 163/1997, Eduskunnan täysistunnon pöytäkirja 8.12.1997, Valtioneuvoston selvitys Suomen alustavista kannanotoista Agenda 2000-asiakirjaan. https://www.eduskunta.fi/FI/vaski/Poytakirja/ Documents/ptk_163+1997.pdf(Tarkistettu 25.2.2019).

PTK 92/1999, Eduskunnan suullinen kyselytunti 18.11.1999. No: 172, Pohjoisen ulottuvuuden sisältö. https://www.eduskunta.fi/FI/vaski/Poytakirja/Documents/ptk_92+1999.pdf(Tarkistettu 25.2.2019).

PTK 87/2001, Eduskunnan täysistunnon pöytäkirja 5.9.2001, Suomen turvallisuus- ja puolustuspolitiikka 2001, https://www.eduskunta.fi/FI/vaski/Poytakirja/Documents/ptk_87+2001.pdf(Tarkistettu 7.8.2019).

PTK 69/2005 vp, Eduskunnan täysistunnon pöytäkirja 8.6.2005, Pääministerin ilmoitus pohjoisesta 
ulottuvuudesta ja ajankohtaisista EU-asioista, PI 3/2005. https://www.eduskunta.fi/FI/vaski/Poytakirja/Documents/ptk_69+2005.pdf (Tarkistettu 7.8.2009).

PTK 76/2006, Eduskunnan täysistunnon pöytäkirja 21.6.2006, Pääministerin ilmoitus puheenjohtajakauden tavoitteista, PI 2/2006, https://www.eduskunta.fi/FI/vaski/Poytakirja/Documents/ ptk 76+2006.pdf (Tarkistettu 25.2.2019).

PTK 70/2007 vp, Eduskunnan täysistunnon pöytäkirja 24.10.2007, Pohjoinen ulottuvuus ja Itämeri -keskustelu, https://www.eduskunta.fi/FI/vaski/Poytakirja/Documents/ptk_70+2007.pdf(Tarkistettu 7.8.2019).

Tuomioja, Erkki (2005), Puhe Northern Dimension Beyond 2006 -konferenssissa 10.10.2005. https:// www.eilen.fi/fi/167/?language $=$ en (Tarkistettu 25.2.2019).

Stubb, Alexander (2006), Raportin A6-0367/2006 esittelypuheenvuoro, Euroopan parlamentin istunto, 15.11.2006, http://www.europarl.europa.eu/sides/getDoc.do?pubRef=-//EP// TEXT+CRE+20061115+ITEM-015+DOC+XML+V0//EN (Tarkistettu 21.2.2019).

UaVL 14/2018, Ulkoasiainvaliokunnan lausunto, Pohjoinen ulottuvuus: tilannekatsaus ja tulevaisuuden näkymät, 30.1.2019, https://www.eduskunta.fi/FI/vaski/Lausunto/Sivut/UaVL_14+2018.aspx (Tarkistettu 7.8.2019).

UaVM 7/2007 vp, Ulkoasiainvaliokunnan mietintö, Itämeri ja Pohjoinen ulottuvuus, 19.10.2007, https://www.eduskunta.fi/FI/vaski/Mietinto/Documents/uavm_7+2007.pdf(Tarkistettu 21.2.2019).

VNS 2/2001 vp, Valtioneuvoston selonteko eduskunnalle, Suomen turvallisuus- ja puolustuspolitiikka, 13.6.2001. https://www.defmin.fi/files/1147/selonteko2001.pdf (Tarkistettu 6.8.2019).

Vanhanen, Matti (2004). Pääministeri Matti Vanhasen Martti Ahtisaari -luento Jyväskylässä 30.11.2004, https://www.eilen.fi/fi/416/?language=fi (Tarkistettu 25.1.2019).

\section{Kirjallisuus}

Aalto, Pami, Blakkisrud, Helge \& Smith, Hanna (2008), Introduction. - The New Northern Dimension of European Neighbourhood. Centre for European Policy Studies.

Averre, Derek (2010), Competing Rationalities: Russia, the EU and the "Shared Neighbourhood". - Europe-Asia Studies 61 (10), 1689-1713. DOI 10.1080/09668130903278918.

Averre, Derek (2011), Competing Rationalities: Russia, the EU and the "Shared Neighbourhood" - The European Union, Russia and the Shared Neighbourhood. Eds. Jackie Gower \& Graham Timmis. Routledge, 5-29.

Averre, Derek (2016), The Ukraine Conflict: Russia's Challenge to European Security Governance. - Europe-Asia Studies 68(4), 699-725. DOI 10.1080/09668136.2016.1176993.

Browning, Christopher S. (ed.) 2005, Remaking Europe in the margins. Northern Europe after the enlargements. Ashgate: Ashgate.

Busygina, Irina \& Filippov, Mikhail (2008). End comment: EU-Russian relations and the limits of the Northern Dimension. - The New Northern Dimension of the European Neighbourhood. Eds. Pami Aalto, Helge Blakkisrud \& Hanna Smith. Brussels: Centre for European Policy Studies, 204-218.

Catellani, Nicola (2003), The EU's Northern Diomension. Testing a New Approach to Neighbourhood Policy. Utrikerpolitiska Institutet. http:/www.catellani.info/wp-content/uploads/2014/04/ UI-Report1.pdf. (Katsottu 7.8.2019)

Cebesi, Münevver (2012), European Foreign Policy Reconsidered: Constructing an "ideal Power Europe" through theory. - Journal of International Studies 40 (3), 563-583. DOI $10.1177 / 0305829812442235$.

Conde Pérez, Elena \& Yaneva, Whaklin (2016), The European Arctic Policy in progress. - Polar Science 10, 441-449. DOI 10.1016/j.polar.2016.06.008.

Cottey, Andrew (2012), Regionalism and the EU's Foreign Policy: The limits of the Possible. Southeast European and Black Sea Studies 12 (3), 375-391. DOI 10.1080/14683857.2012.711090.

Delcour, Laure (2011), Shaping the Post-Soviet Space? EU Policies and Approaches to RegionBuilding. England: Ashgate.

Forsberg, Tuomas \& Haukkala, Hiski (2016), The European Union and Russia. London: Palgrave.

Gebhard, Carmen (2013), Soft Competition: Finland, Sweden and the Northen Dimension of the European Union. - Scandinavian Political Studies 36 (4), 365-391. DOI 10.1111/1467-9477.12007.

Haglund, Anne (2005), The "Northern Dimension". North-Western Russia in focus. - Perspectives on EU-Russia relations. Europe and the Nation State. Eds. Debra Johnson \& Paul Robinson. New 
York: Routledge, 87-102.

Haglund-Morrissey, Anne (2008), Conceptualizing the New Northern Dimension: A Common Policy Based on Sectoral Partnership. - Journal of Contemporary European Studies 16 (2), 203-217. DOI $10.1080 / 14782800802309839$.

Haukkala, Hiski (2010), The EU-Russia Strategic Partnership. The limits of post-sovereignty in international relations. London, New York: Routledge.

Haukkala, Hiski (2015), From Cooperative to Contested Europe? The Conflict in Ukraine as a Culmination of a Long-Term Crisis in EU-Russia Relations. - Journal of Contemporal European Studies 23 (1), 25-40. DOI 10.1080/14782804.2014.1001822.

Heikkilä, Markku (2006), The Northern Dimension. Europe Information, Ministry for Foreign Affairs of Finland, Helsinki.

Horký-Hluchán̆, Ondřej \& Kratochvil, Petr (2014), "Nothing Is Imposed in This Policy!”: The Construction and Constriction of the European Neighbourhood. - Alternativea: Global, Local, Political 39 (4) 2014, 252-270. DOI 10.1177/0304375415574453.

Johansson-Nogués, Elisabeth (2009), Is the EU's Foreign Policy Identity an Obstacle? The European Union, The Northern Dimension and the Union for the Mediterranean. - European Political Economy Review 9, 24-48.

Jokela, Juha (2011), Europeanization and Foreign Policy. State Identity in Finland and Britain. London, New York: Routledge.

Kaelble, Hartmut (2009), Identification with Europe and politicization of the EU since the 1980s. - European Identity. Eds. Jeffrey T. Checkel \& Peter J. Katzenstein. UK: Cambridge University Press, 193-212.

Kelley, Judits (2006), New Wine in Old Wineskins: Promoting Political Reforms through the New European Neighbourhood Policy. - Journal of Common Market Studies 44 (1), 29-55. DOI 10.1111/j.1468-5965.2006.00613.x.

Koski, Leena (2011), Teksteistä teemoiksi - dialoginen tematisointi. - Menetelmäviidakon raivaajat. Perusteita laadullisen tutkimustavan valintaan. Toim. Anu Pusa ja Pauli Juuti. Helsinki: Johtamistaidon opisto, 126-149.

Kosov, Yuri \& Gribanova, Galina (2016), EU Strategy for the Baltic Sea Region: Challenges and Perspectives of International Cooperation. - Baltic Region 8 (2), 33-44. DOI 10.5922/2079-85552016-2-3.

Lipponen, Paavo (1997), The European Union needs a policy for the Northern Dimension. - Europe's Northern Dimension: the BEAR meets the south. Eds. Lasse Heininen \& R. Langlais. Rovaniemi: University of Lapland, 29-35.

Lipponen, Paavo (1998), The European Union Needs a Policy for the Northern Dimension. - The New North of Europe. Perspectives on the Northern Dimension. Eds. Lassi Heininen \& Jyrki Käkönen. Tampere: Tampere University Research Institute, 125-132.

Loukacheva, Natalia (2007), The Arctic Promise: Legal and Political Autonomy of Greenland and Nunavut. University of Toronto Press, Toronto.

Miller, Patrik (2012), Europeanisation within and beyond the EU: A Conceptual overview. - Understanding European Neighbourhood policies. Concepts, actors, perceptions. Eds. Edmund Ratka \& Olga A. Spaiser. Maden Maden: Nomos.

Moshes, Arkady (2012), Russia's European policy under Medvedev: how sustainable is a new compromise? - International Affairs 201288 (1), 17-30. DOI 10.1111/j.1468-2346.2012.01054.x.

Nitoiu, Cristian (2014), EU-Russia Relations. Between Conflict and Cooperation. - International Politics 51 (2), 234-253. DOI 10.1057/ip.2014.7. DOI 10.1057/ip.2014.7.

Numminen, Lotta (2011), Arktisen alueen muuttuva kansainvälinen yhteistyö. - Jäitä poltellessa. Suomi ja arktisen alueen tulevaisuus. Toim. Lassi Heininen \& Teemu Palosaari. Tampere: Rauhanja konfliktintutkimuskeskus TAPRI.

Ojanen, Hanna \& Raik, Kristi (2017), Ulko- ja turvallisuuspolitiikka: pinnallista jatkuvuutta ja pyörteisiä pohjavirtauksia. - Reunalla vai ytimessä. Suomen EU-politiikan muutos ja jatkuvuus. Toim. Tapio Raunio \& Juho Saari. Helsinki: Gaudeamus, 170-195.

Ojanen, Hanna \& Raunio, Tapio (2018), Re-assessing Finland's Integration Policy: The End of Domestic Consensus. - Nordic states and European integration: Akward partners in the north. Eds. Malin Stegman McCallion, \& Alex Brianson. Palgrave McMillan, 33-58.

Pop, Adrian (2016), From cooperation to confrontation: the impact of bilateral perceptions and inter- 
actions on the EU-Russia relations in the context of shared neighborhood. - Eastern Journal of European Studies 7 (2), 47-70.

Prozorov, Sergei (2006), Understanding conflict between Russia and the EU. The limits of the integration. New York: Palgrave Macmillan.

Raik, Kristi (2015), Renaissance of realism, a new stage of Europeanization, or both? Estonia, Finland and EU foreign policy. - Cooperaton and Conflict 50 (4), 440-456. DOI 10.1177/0010836714560033.

Raspotnik, Andreas (2018), The European Union and the Geopolitics of the Arctic. USA: Edward Elgar Publishing.

Raunio, Tapio \& Saari, Juho (2017), Johdanto: onko konsensuksen aika ohi? - Reunalla vai ytimessä? Suomen EU-politiikan muutos ja jatkuvuus. Helsinki: Gaudeamus, 9-25.

Reisigl, Martin \& Wodak, Ruth (2009), The Discource-historical Approach (DHA). - Methods of Critical Discource Analysis. Eds. Ruth Wodak \& Michael Meyer. Los Angeles: Sage.

Rytövuori-Apunen, Helena (2007), Unionin ajan idänpolitiikka. Helsinki: Edita.

Shlyamin, Valery A (2004), Russia in the Northern Dimension. Oulu: Euregio Karelia.

Sicard Filteborg, Mette, Gänzle, Stefan \& Johansson, Elisabeth (2002), An Alternative Theoretical Approach to EU Foreign Policy. "Network Governance" and the Case of the Northern Dimension Initiative. - Cooperation and Conflict: Journal of the Nordic International Studies Association 37 (4), 387-407. DOI 10.1177/001083602762574478.

Smith, Karen E. (2005), The Outsiders: The European Neighbourhood Policy. - International Affairs 81 (4), 757-773. DOI 10.1111/j.1468-2346.2005.00483.x.

Tomala, Magdalena (2017), The European Union's Relations With Greenland. - International Studies: Interdisciplinary Political and Cultural Journal 20 (1), 31-46. DOI 10.1515/ipcj-2017-0015.

Van Elsuwege, Peter (2008), The Four Common Spaces: New Impetus to the EU-Russia Strategic Partnership. - Law and Practise of EU External Relations. Salient Feature of a Changing Landscape. Ed. Alan Dashwood. Cambridge University Press, 334-359.

Wider Europe - Neighbourhood: A New Framework for the Relations with our Eastern and Southern Neighbours 2003. Communication from the Comission to the Council and the European Parliament. Comission of the Euroean Communities. http://eeas.europa.eu/archives/docs/enp/pdf/pdf/ com03_104_en.pdf (Tarkistettu 26.9.2019)

Zaiotti, Ruben (2007), Of Friends and Fences: Europe's Neighborhood Policy and the 'Gated Community Syndrome'. - Journal of European Integration 29 (2), 143-162. DOI 10.1080/07036330701252581.

Østhagen, Andreas (2013), “The European Union - An Arctic Actor?" - Journal of Military and Strategic Studies 15 (2): 71-92. 